Катасонов В. Н. Аостоевский и феноменология // Философия. Журнал Высшей школы экономики. -2021 . - Т. 5, № 3. - С. 73-91.

\title{
ВЛААИМИР КАТАСОНОВ*
}

\section{АОСТОЕВСКИЙ И ФЕНОМЕНОЛОГИЯ**}

Получено: 12.06.2021. Рецензировано: 26.08.2021. Принято: 28.08.2021.

Аннотация: В статье обсуждается близость художественных приемов Ф. М. Аостоевского методам философской феноменологии. Через особую постановку голоса автора в произведениях писателя универсум его героев представляет собой своеобразный аналог Lebenswelt Гуссерля. Голос автора, рассказчика в полифоническом романе, служит медиумом, благодаря которому выявляется фундаментальная духовная позиция, лик героя. В статье показано, что далеко не сразу писателю удалось найти решение этой сложной задачи: с одной стороны, голос и видение автора должны быть всеобъемлющими, а с другой - не претендующими на последнюю правду, сохраняющими диалогическую открытость повествования, затрагивающего фундаментальные вопросы человеческого бытия. Анализируя сохранившиеся черновые материалы романов, автор статьи показывает, как, по существу, только в «Бесах» Аостоевскому удается найти приемлемое решение этой задачи («хроникер»). На примере анализа рассказа «Кроткая» в статье демонстрируется сходство приемов Достоевского и метода феноменологической редукции. Самопознание героя рассказа представляет собой своеобразную феноменологическую процедуру, в которой осуществляется «заключение в скобки» всех внешних обстоятельств жизни человека-психологических, социальных, исторических - ради выявления фундаментальной духовной позиции героя по отношению к Богу и Аругому. Человек в этом акте самопознания как бы поднимается над самим собой, преодолевает все случайное и поверхностное в своей жизни и предстает перед нами своим онтологическим лицом (ликом), открывая перед лицом Бога свою последнюю правду. Автор статьи понимает эту близость как неслучайную: само происхождение анализа сознания в феноменологии связано с традицией культуры покаяния в христианской церкви.

Ключевые слова: полифонический роман, голос автора, хроникер, «жизненный мир» Гуссерля, феноменологическая редукция, покаянный анализ совести.

DOI: $10.17323 / 2587-8719-2021-3-73-91$.

Создание философской феноменологии - одно из самых значимых философских событий хх века. Феноменология существенно повлияла на возникновение экзистенциализма, литературу, кино, богословие в хх столетии, породило целый спектр конкретных феноменологических исследований. Освоение философской феноменологии - дело непростое: по опыту преподавания этой дисциплины знаю, что студенты поначалу вообще не понимают, о чем идет речь. И действительно, феноменология

*Катасонов Владимир Николаевич, д. филос. н., д. богосл., профессор; Общецерковная аспирантура и докторантура имени святых равноапостольных Кирилла и Мефодия (Москва), vladimir15k@mail.ru, ORCID: 0000-0002-4933-3004.

** (C) Катасонов, В. Н. (C) Философия. Журнал Высшей школы экономики. 
требует изменить направление внимания, с естественного - на предмет, на специальное, ориентированное на сами акты сознания. Феномен феноменологической философии есть не просто явление какой-то сущности, как говорит нам традиционная философская и научная терминология. Подобное понимание феномена Хайдеггер называл вулъгарнымм пониманием. Парадокс в том, что феномен и оказывается той сущностью, которую надо усмотреть... Речь идет об особой практике самонаблюдения сознания, без освоения которой все рассуждения о феноменах окажутся лишь «словами». Шелер сравнивает философские рассуждения, философские понятия с использованием денежных купюр (или векселей). Все операции с купюрами имеют смысл, только если возможен их обмен на золото. Иначе это просто бумага... Также можно спросить и о философских категориях: исполняется ли где-то предметный смысл всего этого философского говорения или же оно остается самодостаточно замкнутым в себе?.. Именно на усмотрение этого предметного обеспечения философии и направлена работа феноменологии (Шелер, Денежкин и др., 1994: 213).

Непосредственное усмотрение феномена представляет нередко непростую задачу. Феномен обычно бывает смешан с другими феноменами, он оказывается сложным. Выделить из него простой феномен очень нелегко. Хайдеггер пишет, что феномен может быть «засорен», его необходимо очистить (Хайдеггер, Бибихин, 1997: 36).

Такую же процедуру очищения феноменов предлагает и Гуссерль. Вещи мира для нас выступают всегда уже как интерпретации: нет просто красного цвета, нет просто дерева, нет просто живого; всегда мы имеем дело с уже состоявшимися сравнениями и объяснениями: красный как кровь, дерево, например липа, животное как живое и т. д. Очистить восприятие от этих дополнительных соотнесений, увидеть феномен в чистом виде и есть задача феноменолога. Этот мир чистых феноменов Гуссерль называет жизненным миром (Lebenswelt). Понятие жизненного мира у Гуссерля достаточно сложно и неотчетливо. Жизненный мир есть как бы мир естественного восприятия (ребенка?), еще ненагруженного никакими научными и бытовыми интерпретациями, как бы мир глазами дикаря, но в то же время это есть мир восприятий, в котором выступает сама истина бытия вещей, сама их суть.

Мы рассмотрим здесь, как Ф.М. Достоевский в своем творчестве еще до возникновения всякой философской феноменологии применял некоторые ментальные процедуры, которые потом вошли в классический инструментарий феноменологии. И, в частности, в своих произведениях, 
в особенности - в романах, он строил свой вариант «жизненного мира», может быть, еще более, чем классический, соответствующий своему названию.

\section{1. ПРОБЛЕМА АВТОРСКОГО ГОЛОСА И LEBENSWELT}

\section{У Ф. М. ДОСТОЕВСКОГО}

Ту удивительную форму романов Достоевского, которая узнается сразу с нескольких строк, М. М. Бахтин назвал полифоническим романом. Смысл этой формы в том, что писатель умел изображать жизнь самосознания своих героев. Герои Достоевского вовлечены в большой жизненный диалог, они решают серьезные мировоззренческие проблемы. Решение этих жизненных проблем всегда связано с поступками, с объяснениями и оправданиями перед своей совестью и другими людьми, перед Богом. Эти решения не могут быть сведены только к какой-то формуле. Как и сама жизнь, они реализуются через преодоление сомнений, через усилия, через постоянную рефлексию, бодрствование сознания, диалог с самим собой и другими. Самосознание героев открыто, как открыта и сама жизнь, оно не может кончиться ни с преступлением, ни с приговором.

Бахтин подчеркивает тот момент, что герои Достоевского, во всяком случае в романах, почти все связаны с какой-то довлеющей идеей, являются идеологами. Таков и Раскольников, и подросток, и Версилов, и Иван Карамазов. Достоевский изображает не просто жизнь героя, а одновременно и идею, жизнь идеи. Эта идея всегда воплощена в определенной позиции героя.

Достоевский, говоря парадоксально, мыслил не мыслями, а точками зрения, сознаниями, голосами. Каждую мысль он стремился воспринять и сформулировать так, чтобы в ней выразился и зазвучал весь человек, тем самым в свернутом виде все его мировоззрение от альфы до омеги. Только такую мысль, сжимающую в себе цельную духовную установку, Достоевский делал элементом своего художественного мировоззрения; она была для него неделимою единицей; из таких единиц слагалось уже не предметно объединенная система, а конкретное событие организованных человеческих установок и голосов (Бахтин, 2002: 106).

В этих голосах и индивидуализированных сознаниях нам видится отражение глубинных черт христианского опыта, давно и тщательно прорефлектированного в православном богословии. Мир Достоевского есть мир личностей, все идеи, все вещи даны через призму их восприятия личностями. В.Н. Лосский пишет (Лосский, 1991: 129): 
...наше представление о человеческой личности как о чем-то «личностном», делающем из каждого человеческого индивида существо «уникальное», совершенно ни с кем не сравнимое и к другим индивидуальностям несводимое, дало нам именно христианское богословие. Философия древнего мира знала только человеческие индивиды. Человеческая личность не может быть выражена понятиями. Она ускользает от всякого рационального определения и даже не поддается описанию, так как все свойства, которыми мы пытались бы ее охарактеризовать, можно найти и у других индивидов. «Личное» может восприниматься в жизни только непосредственной интуицией или же передаваться каким-нибудь произведением искусства. Когда мы говорим: «Это-Моцарт» или «это-Рембрандт», то каждый раз оказываемся в той «сфере личного», которой нигде не найти эквивалента.

Собственно, и изображения вещей как таковых, безразличных от человеческого присутствия, в произведениях писателя не так много. Обычно вещи служат каким-то символом человеческого состояния ${ }^{1}$. Единицей мира Достоевского служит человеческая ипостасъ в богословском смысле этого слова, не индивидуальность, наделенная той или иной природой, а человеческая личность, свободно избирающая свою мировоззренческую позицию перед лицом Бога и людей. Конечно, обычно герои наделены и какими-то природными, психологическими или социологическими качествами: молодые, старые, больные, здоровые, мещане, дворяне, красивые, уродливые и т. д. Но все эти качества играют у Достоевского второстепенную роль, они как бы отходят на второй план перед основной интенцией писателя - показать особенность мировоззренческой позиции героя в общении с другими героями. Более того, эти материальные характеристические особенности порой даже мешают разглядеть главный феномен личности, скрывающийся за ними. Говоря словами Хайдеггера, феномен личности должен быть очищен. Личность несводима к качествам, к индивидуальности, ее невозможно понять по свойствам. Личность можно опознать, с ней можно встретиться только в непосредственном феноменологическом восприятии .

Для изображения жизни самосознания, жизни личности Достоевский должен был решить принципиальную задачу голоса автора. Автор у До-

${ }^{1}$ Ср. дверной колокольчик в «Преступлении и наказании» (Дзо. Т. 6: 67).

${ }^{2}$ Говоря так, мы, конечно, расширяем понятие феноменологического восприятия. Гуссерль говорил только о феноменах вещей и идей. Но восприятие личности тем более не может ограничиться опознанием отдельных черт индивидуальности и требует целостного схватывания феномена. Ближе к нашей позиции находятся размышления М. Шелера, говорившего о чистых личностных типах (Шелер, Денежкин и др., 1994). 
стоевского уже не может представлять окончательную истину о своих героях: жизнь их, пока они живы, всегда открыта, они могут оспорить любую заочную оценку себе (вспомним «человека из подполья»). Бахтин пишет (Бахтин, 2002: 74):

Итак, новая художественная позиция автора по отношению к герою в полифоническом романе Достоевского - это всерьез осуществленная и до конца проведенная диалогическая позиция, которая утверждает самостоятельность, внутреннюю свободу, незавершенность и нерешенность героя. Герой для автора не «он»и не «я», а полноценное «ты», то есть другое чужое полноправное «я»(«ты еси»).

Однако как реализовать эту диалогическую позицию, не нарушая композиционного целого романа? Как утвердить конкретные описания жизни героя и в то же время оценочную нейтральность автора, который, как говорится, «любит всех своих героев»?

Достоевский с самого начала своего творчества ищет лексических и композиционных возможностей реализовать эту идею абсолютно объективного автора. Как показывает Бахтин, уже Макар Девушкин из «Бедных людей» (1846) дан нам так, что оспаривает всякое внешнее заочное определение своей сущности (автором), не оставляющее ему никаких новых перспектив. Ярчайшим выражением этого бунта героя против автора, но уже возведенного из чисто композиционной проблемы до задачи нравственного самопознания, являются «Записки из подполья», где герой яростно спорит против любого внешнего определения, представляясь почти чистым (Сартровским) ничто... Достоевский умел строить повествование так, что позиция автора по отношению к герою становилась не окончательным приговором последнему, а также вовлекалась в диалог, оценивалась самим героем. В плане лексики для реализации этой цели, как показал Бахтин, Достоевский мастерски использовал так называемое «многоголосое слово» (там же: 115-279).

Рассказ там, где он не вмешивается, как чужой голос, во внутренний диалог героев, где он не вступает в перебойное соединение с речью того или другого из них, дает факт без голоса, без интонации или с интонацией условной. Сухое, осведомительное, протокольное слово-как бы безголосое слово, сырой материал для голоса. Но этот безголосый и безакцентный факт дан так, что он может войти в кругозор самого героя и может стать материалом для его собственного голоса, материалом для его суда над самим собою. Своего суда, своей оценки автор в него не вкладывает (там же: 279). 
Задача голоса автора решалась писателем на протяжении всей его творческой жизни. И нужно сказать, что где-то в начале 7о-х годов она была в главном решена. Проследим вкратце по черновикам романов несколько этапов решения этой задачи.

Роман «Преступление и наказание» (1866). Произведение писалось тяжело, известны три черновые редакции романа, и в них проблема автора упоминается не раз. В подготовительных материалах третьей редакции мы читаем (Дзо. Т. 6: 146):

Рассказ от имени автора, как бы невидимого, но всеведущего существа, но не оставляя его ни на минуту, даже со словами: «и до того все это нечаянно сделалось».

Достоевский сам фиксирует здесь определенное противоречие между всеведущим существом и нечаянно сделалосъ. Для описания самосознания нужно всеведущее существо, но для криминального романа многое должно произойти нечаянно. Как совместить это?..

Тут же рядом Достоевский пишет: «Предположить нужно автора существом всеведующим и не погрешающим, выставляющим на вид одного из членов нового поколения〉 (там же: 149). Автор должен быть не погрешающим, т. е. стоящим на правильной точке зрения... Но что это значит?.. Как найти эту правильную точку зрения, в особенности в то переходное время, в которое писался роман?.. Все это показывает нам, какие сложнейшие идейные и композиционные проблемы должен был решать Достоевский по ходу написания романа.

Наброски к роману «Идиот» (1868). Этот произведение Достоевский считал своим самым любимым романом. Роман, который в подготовительных материалах писатель называет «Роман о христианине», главную цель которого он формулирует как «изобразить положительно прекрасного человека». Характеризуя рассказчика, Достоевский пишет (в подготовительных материалах): «Рассказ вроде пушкинского (краткий и без объяснений, психологически откровенный и простодушный)» (Д3о. Т. 9: 115). Писатель апеллирует здесь к пушкинской прозе, особенно, конечно, к «Повестям Белкина». На тему голоса рассказчика у Пушкина существует множество работ, среди них есть замечательные 3 .

${ }^{3}$ Академик В. В. Виноградов писал: «В „Повестях Белкина“ образ автора складывается из сложных стилистических отношений между „издателем“, автором, его биографомдругом автора и рассказчиками. Ближайшие историко-литературные корни этой манеры повествования нетрудно отыскать в сочинениях Вальтер-Скотта. Гораздо труднее понять приемы и принципы соотношения разных стилистических и идейно-характеристических 
В другом месте подготовительных материалов к «Идиоту» читаем:

NotaBene. Тон (рассказ-житие - т. е. хоть и от автора, но сжато, не скупясь на изъяснения, но и представляя сценами. Тут надо гармонию). Сухость рассказа, иногда до «Жиль Блаза». На эффектных и сценических местахкак бы вовсе этим нечего дорожить. // Но и владычествующая идея жития чтоб видна была - т. е. хотя и не объяснять словами всю владычествующую идею и всегда оставлять ее в загадке, но чтоб читатель всегда видел, что идея эта благочестива, что житие - вещь до того важная. что стоило начинать даже с ребяческих лет. Тоже-подбором того, об чем пойдет рассказ, всех фактов как бы беспрерывно выставляется что-то и беспрерывно постановляется на вид и на пьедестал будущий человек. // Чтоб в каждой строчке было слышно: я знаю, что я пишу, и не напрасно пишу (Дзо. Т. 9: 132-133).

Достоевский хочет иметь рассказчика житийного жанра, который создает как бы икону личности, в том смысле, что не отдельные события жизни героя важны сами по себе, а что все они дают нам представление о целом, что это целое как бы просвечивает через каждый конкретный момент жизни («даже с ребяческих лет»). Подобный рассказчик, подобный голос автора нужен для того, чтобы показать лик героя, то своеобразие его личности, с которым он входит в универсум человеческой истории, в вечность.

Но проблема соотношения в голосе автора «вечного» и исторического остается. Достоевский постоянно подчеркивает, что следует «писать одними фактами», «писать в смысле: говорят» (там же: 235-236), желая исключить из голоса автора всякую партикулярность и предвзятость, но тем острее встает вопрос о конечном смысле изображаемого и о способе его присутствия в материи повествования.

Роман «Бесы» (1871-1872). В этом произведении Достоевский как бы нашел решение стоявшей перед ним задачи голоса рассказчика. Роман идейно очень сложный: в нем сталкиваются противоположные мировоззрения разных степеней контрарности, поэтому он в особенности требовал «деликатной» позиции автора, чтобы не возникло впечатления, будто автор прикрыто «протаскивает» какую-то свою предвзятую идею. Роман писался с надрывами, Достоевский бросал старые редакции и начинал новые, но интересно, что уже с самого начала у него появляется идея хроникера. В подготовительных материалах к роману мы довольно часто встречаем это имя. «Систему же я принял ХРоники»,-- отмечает

оболочек в структуре этого многоликого „образа писателя“ и установить их социальноязыковую и национально-типическую сущность» (Виноградов, 2021). 
писатель; «Из губернской хроники», «Хроникер от себя» (Дзо. Т. 11: 92, 96). Повествователь Антон Лаврентьевич Г-ов в «Бесах» есть та художественная оптика, через которую мы смотрим на все события. Более того, Достоевский склонен использовать своего хроникера и в повествованиях о событиях, свидетелем которых он не был (там же: 96):

Вообще, если я описываю разговоры даже сам-друг-не обращайте внимания: или я имею твердые данные, или, пожалуй, сочиняю сам-но знайте, что все верно.

Хроникер есть живой человек, ему свойственны и юмор, и собственные акценты в событиях («Хроникер от себя: а знаете, я все-таки не считаю этого важным (т. е. нигилистов). Как хотите, это неважно (юмористично, кратко и с меткими выражениями)» (там же: 145), но тем не менее он есть то «всевидящее око», которое дает нам полную картину романа.

Нас интересует здесь формальная сторона постановки голоса автора у Достоевского. Мы не обсуждаем сейчас содержательную, идеологическую сторону этого вопроса. Тем не менее, думаем, полезно сослаться на обширную работу Ю. Корякина, посвященную именно содержательному аспекту. В статье «Зачем Хроникер в „Бесах“?» автор пишет (Карякин, 1981: 83):

Сочетание предельной объективности (Хроникер сообщает «чистые» факты) с предельной же субъективностью (оценки фактов даны от имени колеблющегося и как бы не авторитетного лица) оказывается чрезвычайно продуктивным художественно: читатель, имея необходимую и точную информацию о событиях, получает и мощный стимул к свободному и полемическому сотворчеству. А это самое главное, потому что живой читатель - все для Достоевского. // Хроникер и стимулирует это сотворчество. Стимулирует и простодушным и ироничным тоном своим. [...] В этом неожиданном и органическом приобщении его к «предвечным вопросам»-выражение принципиального, так сказать, мировоззренческого демократизма Достоевского, выражение глубоко скрытой, но и глубоко существующей, реальной конгениальности людей, способности их к бесконечному развитию (то есть к взаимопониманию).

Роман «Подросток» (1875) дает мало для нашей темы, так как все повествование представляет собой рассказ от первого лица главного героя Аркадия Долгорукого. В подготовительных материалах Достоевский сам отмечает ограниченность кругозора рассказчика его возрастом:

ЗАмЕЧАНИЕ: Подростку, в его качестве молокососа, и не открыты (не открываются и ему их не открывают) происшествия, факты, фабулу романа. Так 
что он догадъвается об них и осиливает их сам. Что и обозначается во всей манере его рассказа (для неожиданности, для читателя) (Дзо. Т. 16: 48-49).

Характеристические особенности самосознания подростка во многом заслоняют здесь других героев: «Исповедь необычайно сжата (учиться у Пушкина). Множество недосказанностей. Своя манера... // СжАТЕЕ, КАК МОЖно СЖАТЕЕ» (там же: 47).

«Братъя Карамазовы» (1879-1880). Наиболее совершенный роман Достоевского, который должен был стать по замыслу автора первой частью дилогии об Алеше Карамазове. Писатель в совершенстве владеет искусством описывать события глазами рассказчика («биограф»), то приближая его к читателю, даже полемизируя с ним через предвосхищаемые реплики, то полностью растворяя биографа в чисто объективном рассказе. В черновиках к роману мы совсем не находим постановки вопроса о голосе автора.

Тем самым мы видим, что решающим моментом в поиске позиции автора, рассказчика, биографа был именно роман «Бесы» и работа над ним. Позиция хроникера оказалась для Достоевского наиболее адекватной для реализации его главной интуиции - построения полифонического романа. Критики отмечают, что идея рассказчика и связанные с ней композиционные, лексические и идеологические проблемы все время присутствовали в работах Достоевского. Составитель «Энциклопедии» о Достоевском пишет (Наседкин, 2008: 485-486):

Хроникер из «Дядюшкиного сна» стоит в ряду многочисленных героеврассказчиков и авторов «записок» в мире Достоевского, - таких, как: Неизвестный, Мечтатель, Неточка Незванова, Маленький герой, Сергей Александрович, Подпольный человек, Семен Семенович Стрижев, Алексей Иванович, Антон Лаврентвевич Г-ов, Аркадий Долгорукий, Александр Петрович Горянчиков, Повествователь («Братья Карамазовы»).

Образ рассказчика так важен для Достоевского потому, что показать личность героя можно только через взгляд другого человека, но чтобы этот взгляд не оказался приговаривающим взглядом монологического автора, отнимающего у героя его свободу, сам этот рассказчик должен находиться в диалогических отношениях с героями. Рассказчик в той или иной степени всегда оказывается также героем произведения со своей собственной более или менее серьезной точкой зрения на обсуждаемые вопросы, но он всегда композиционно наличен. Личность может быть опознана только личностью, и личность рассказчика является 
здесь тем инструментом, детектором, которым писатель исследует личности своих героев.

Мир героев Достоевского, мир их самосознаний в отношении с другими сознаниями, мир личностей представляет собой своеобразный Lebenswelt русского писателя. Достоевского интересует именно личностная позиция героев по отношению к фундаментальным вопросам человеческого бытия: веры, любви, спасения, греха, преступления... Bce внешнее, все социальные и психологические особенности являются даже помехой, они должны быть редуиированы, заключены в скобки, и все ради опознания живой личностной позиции. В «Бесах», в разговоре Ставрогина с Шатовым, последний в ответ на ернический тон взрывается (Д3о. Т. 10: 195):

Я уважения прошу к себе, требую! - кричал Шатов, - не к моей личности,к чорту ее,- - а к другому, на это только время, для нескольких слов... Мы два существа и сошлись в беспредельности... в последний раз в мире. Оставьте ваш тон и возьмите человеческий!

Шатов говорит «личность», но имеет в виду свою индивидуальность и свое состояние (он болен). Уважения он требует именно к своей личности, как к Другому равноправному существу, смысл существования и самоопределения которого превосходит все исторические и пространственные измерения, принадлежит беспредельности... Именно в этом пространстве беспредельности, в конце концов, и ищут своего места герои Достоевского. Только феноменологически, целостным схватыванием, можно увидеть подобный образ героя, и вся писательская техника, все композиционные приемы писателя направлены именно на усмотрение этой последней правды своих героев.

Несмотря на всю свободу самоопределения, которую дает Достоевский своим героям, несмотря на все равноправие их участия в большом мировоззренческом диалоге, который развертывается на страницах его произведений, универсум мировоззренческих позиций оказывается тем не менее иерархически упорядоченным. Выражаясь словами М. Шелеpa, писатель представляет нам свой Ordo amoris (Шелер, Денежкин и др., 1994: 339-376), свой порядок любви, нерасторжимо связанный с традицией Православия. Бахтин пишет (Бахтин, 2002: 163-164):

В результате такого идеологического подхода перед Достоевским развертывается не мир объектов, освещенный и упорядоченный его монологическою мыслью, но мир взаимно освещающихся сознаний, мир сопряженных смысловых человеческих установок. Среди них он ищет высшую авторитетнейшую 
установку, и ее он воспринимает не как свою истинную мысль, а как другого истинного человека и его слово. В образе идеального человека или в образе Христа представляется ему разрешение идеологических исканий. Этот образ или этот высший голос должен увенчать мир голосов, организовать и подчинить его.

\section{2. ФЕНОМЕНОЛОГИЯ «КРОТКОЙ»Ф. М. ДОСТОЕВСКОГО}

Наша задача - не применение феноменологического метода к анализу произведения великого писателя, а демонстрация того, что Достоевский, по существу, сам исполъзует феноменологический метод. Причем это использование феноменологического подхода не есть что-то случайное, маргинальное в творчестве писателя. Практически это есть один из главных методов работы Достоевского, применение которого и создает ту неповторимую «фантастическую» атмосферу его произведений - «мир героев Достоевского». Многие, да, собственно, и почти все центральные герои Достоевского, заняты самопознанием, стремлением понять самих себя. Cognosce te ipsum оказывается далеко не простой задачей, а решением своеобразной загадки, сложность которой состоит именно в том, что ответ на нее вроде бы и всегда рядом, поскольку он есть я сам, но в то же время понять, что я есть в сердцевине своих желаний, побуждений, мечтаний, умолчаний, открыть это, признаться себе в этом оказывается чрезвычайно трудным делом. Эти экзистенциальные загадки нередко дают ключ ко всей жизненной ситуации героя. Достоевский удивительно умел показывать этот процесс раскрытия правды о себе самом того или иного героя. В этом мучительном процессе самопонимания, пути $\kappa$ себе самому находятся Раскольников, Ставрогин, Шатов, Кириллов, Иван Карамазов, Катерина Ивановна, Лиза Хохлакова и др. Метод, которым пользуется здесь Достоевский,продвижение к экзистенциальной правде о человеке- - дивительно близок методу феноменологической редукиии, этому очищению изучаемого объекта от всего второстепенного и поверхностного, выявлению центрального феномена, который обычно уже не редуцируем к словесному определению, а дан лишь непосредственному созерцанию.

Мы рассмотрим работу этого метода у Достоевского на примере его гениального рассказа «Кроткая», опубликованного в «Дневнике писателя» за ноябрь 1876 года. Итак, герой рассказа, ростовщик-процентщик, один в комнате, где на столе лежит хладный труп его жены, выбросившейся из окна. Герой пытается уяснить самому себе, как же это могло произойти?.. 
...Вот пока она здесь - еще всё хорошо: подхожу и смотрю поминутно; а унесут завтра и - как же я останусь один? Она теперь в зале на столе, составили два ломберных, а гроб будет завтра, белый, белый гроденапль, а впрочем, не про то... Я всё хожу и хочу себе уяснить это. Вот уже шесть часов, как я хочу уяснить и всё не соберу в точку мыслей. Дело в том, что я всё хожу, хожу, хожу… (Дзо. Т. 24: 6)

Герой, типичный персонаж Достоевского, вышедший в результате конфликта с товарищами в отставку офицер, 41 года, до безумия гордый, содержит закладную лавку. Женился на молодой бедной девушкесироте 16 лет. Женился по любви. Но гордость не позволяет герою насладиться семейным счастьем. Старые нравственные раны, «нажитые в грехах» болезни, как говорил Достоевский, а главное-воспалённая гордыня, заставляют его играть перед своей женой роль загадочного человека. Она должна все понять, оценить его благородство и, как говорится, «молиться на него». Поэтому день за днем выматывающий психологический эксперимент: строгость и холодность, демонстрация основательности, благородства, явного, а лучше скрытого...

Начинается игра в «молчанку», порой ссоры. «Кроткая бунтует», как называется одна из главок рассказа, начинает одна уходить из дома. Она узнает о столь неприятной для своего мужа истории в полку в бытность его офицером. И по молодости сразу же попадается «на удочку» одного из главных недругов своего мужа Ефимовича. Последний не только рассказал ей о столь неприятном для мужа инциденте, но и задумал соблазнить молодую жену. У них назначено свидание, а герой, подкупив хозяйку квартиры, где должно было быть свидание, подслушивает их разговор. Но тут он еще раз убеждается в нравственной чистоте своей жены. Герой рассказа входит в комнату, где происходила вся эта сцена, уводит свою жену и... молчит. Молчит все по той же гордости.

На другое утро, на мгновение открыв глаза, он обнаруживает, что его жена поднесла к его виску пистолет. Герой выдерживает все это испытание, как бы доказав, что у него достаточно мужества не бояться смерти, и тем самым как бы оправдавшись перед своей женой, а в ее лице перед всеми (а главное, и перед самим собой!) за ту историю в полку, где его судили за трусость.

Жена полностью побеждена нравственно, даже раздавлена. За нейдве попытки тяжелейших нравственных преступлений - адюльтера и убийства, - ее муж-прокурор противостоит ей как «Монблан» мужества, великодушия и благородства. 
Но герою этого мало. Он продолжает высокомерно молчать. Но вот вдруг ПЕЛЕНА УПАЛА! После целой зимы напряженной «молчанки» супруга вдруг тихонечно запела. Этот факт повергает героя в глубокую оторопь. В душе героя происходит своеобразный «коперниканский переворот»: нравственно «победив» свою жену, герой думает, что внутри своей домашней «Вселенной» он установил вполне однозначный порядок. Он есть солнце этой системы, и все остальное вращается вокруг него... Но вот вдруг в этой, казалось бы, столь устойчивой «планетарной системе» она неумолимо совершает свое равномерное вращение уже целую зиму и обнаруживается сбой: жена поет, как бы не думая о нем, о самом центре этого бытия, не только физическом, финансовом, но, что самое важное, - нравственном!..

Пелена упала с глаз! Герой вдруг обнаруживает, что поет как раз та женщина, которую он полюбил еще тогда, когда она приходила к нему закладывать свои дешевые памятные вещицы, оставшиеся от родителей, которая так радовалась в первые месяцы их совместной жизни, которая так умело и благородно разоблачала развратного проходимца и которую он... все время любил, хотя гордость и нажитые в разврате болезни, как сорняки, заглушали все время эти благодатные цветы любви. Герою так хочется вернуть это благое время, он так желал бы просто поговорить со своей дорогой женушкой, единственным другом, который есть у него! Он возвращается домой и пытается говорить с женой. Герой надеется, что своим хлынувшим клокочущим потоком обожанием ему удастся разбудить в ней опять любовь. Однако все эти исповеди героя, его горячечная страстность только пугают супругу:

Она сама брала меня за руки и просила перестать: «Вы преувеличиваете... вы себя мучаете», - и опять начинались слезы, опять чуть не припадки! Она всё просила, чтобы я ничего этого не говорил и не вспоминал (Дзо. Т. 24: 30).

Наш герой говорит, что хочет везти супругу на море, «в Булонь», чтобы она там поправилась и у них бы началась новая жизнь. Но трагедия неизбежно движется к своей развязке... Герой ушел только на два часа, чтобы побеспокоиться о заграничных паспортах, а в это время жена его, помолившись перед своей иконой и прижав ее к груди, выбросилась из окна на мостовую.

Герой рассказа во что бы то ни стало стремится уяснить себе смысл происходящего. Почему же умерла, убила себя его жена? Во время всей его дьявольской игры в гордость ему все казалось, что жена, оценив его мужество, выдержку, снисходительность и благородство, скрываемые 
под маской строгости, сама бросится наконец к нему в объятия, признает всю его правоту, нравственно поклонится ему... и тогда, только тогда он откроет ей свое любящее сердце и у них начнется счастливая совместная жизнь. Однако жизнь оказалась хитрее всех самых хитрых расчетов. Для любви, как оказалось, нужна была встречная любовь, а не маска строгости, пусть и скрывающая теплящееся под ней живое чувство.

Как слои луковицы, снимает герой со своей души фантомы, мешающие ему увидеть истинный феномен происшедшего, воистину осуществляя философскую феноменологическую редукцию. Ни обстоятельства их жизни, ни явленное им мужество («выдержал револьвер!») несущественны здесь. Он понял вдруг: несмотря на все это, жена его пришла к выводу, что не сможет его любить. А уважала ли хотя бы она его? Ведь он, казалось бы, нравственно полностью победил ее?.. Но новый слой спадающей с умственных очей пелены открывает еще большую глубину трагедии. Он вдруг понимает, что жена его не только не могла его любить, но и по-своему презирала его. Так, постепенно открывается герою его не воображаемый, не тщательно срежиссированный, а тот истинный вид, который он имел в глазах своей жены-самоубийцы.

Но герою нашему открывается не только нравственная оценка его со стороны супруги. Ему постепенно открывается и истина его собственного сердца. Все эти желания разбогатеть, «мстить обществу» и т. д. все это спадает, как пелена, как лишь пустые обертки, скрывающие последнюю правду его сердца.

Мертвая, не слышит! Не знаешь ты, каким бы раем я оградил тебя. Рай был у меня в душе, я бы насадил его кругом тебя! Ну, ты бы меня не любила,и пусть, ну что же? Всё и было бы так, всё бы и оставалось так. Рассказывала бы только мне как другу,- вот бы и радовались, и смеялись радостно, глядя друг другу в глаза. Так бы и жили (Д3о. Т. 24: 35).

Последняя правда открывается герою: для жизни нужен друг, нужна любовь. Только тогда обретает смысл настоящее, в надежде открывается будущее и искупается прошлое. Только тогда жизнь находит свою опору и полноту. А без этого-ад одиночества, хуже всякого бреда. Никакая природа, никакая вселенная не способна насытить, удовлетворить человеческую жажду любви, как онтологической близости с себе подобным. Только в любви, в сочувствии находит человеческая жизнь свое исполнение. 
Косность! О, природа! Люди на земле одни - вот беда! «Есть ли в поле жив человек?»-кричит русский богатырь. Кричу и я, не богатырь, и никто не откликается. Говорят, солнце живит вселенную. Взойдет солнце и- посмотрите на него, разве оно не мертвец? Всё мертво, и всюду мертвецы. Одни только люди, а кругом них молчание-вот земля! «Люди, любите друг друга»-кто это сказал? чей это завет? Стучит маятник бесчувственно, противно. Два часа ночи. Ботиночки ее стоят у кроватки, точно ждут ее... Нет, серьезно, когда ее завтра унесут, что ж я буду? (Дзо. Т. 24: 35)

\section{3. ФЕНОМЕНОЛОГИЧЕСКИЙ МЕТОД У ДОСТОЕВСКОГО}

Достоевский не соглашался, когда его называли психологом. «Меня зовут психологом: неправда, я лишь реалист в высшем смысле, то есть изображаю все глубины души человеческой» (Д3о. Т. 27: 65). Тема познания человека, в особенности самопознания, стояла в центре его писательских задач. И интересно, что за несколько десятилетий до открытия феноменологии Достоевский на примере своих героев, по существу, демонстрирует работу феноменологического метода. Уже в преамбуле «Кроткой», обозначенной «От автора», он пытается дать описание своего метода.

Дело в том, что это не рассказ и не записки. Представьте себе мужа, у которого лежит на столе жена, самоубийца, несколько часов перед тем выбросившаяся из окошка. Он в смятении и еще не успел собрать своих мыслей. Он ходит по своим комнатам и старается осмыслить случившееся, «собрать свои мысли в точку». [...] Ряд вызванных им воспоминаний неотразимо приводит его наконец к правде; правда неотразимо возвышает его ум и сердце. К концу даже тон рассказа изменяется сравнительно с беспорядочным началом его. Истина открывается несчастному довольно ясно и определительно, по крайней мере для него самого (Дзо. Т. 24: 5).

Все это уяснение дела, собрание мыслей в точку и есть поиск феномена, являющего герою и его самого, и супругу в ее истинном свете, и смысл происшедшей драмы. Все эти противоречия, обвинения ее, оправдания себя и т. д.- то, что должно быть подвергнуто феноменологической редукции,- заключено в скобки, ради того чтобы истина решающего феномена осветила все неопровержимым светом очевидности. Достоевский ясно отдает себе отчет в условности его метода.

Теперь о самом рассказе. Я озаглавил его «фантастическим», тогда как считаю его сам в высшей степени реальным. Но фантастическое тут есть действительно, и именно в самой форме рассказа, что и нахожу нужным пояснить предварительно (там же). 
Действительно, форма рассказа, центрирующая наше внимание на самосознании героя, как бы погашающая все реалии внешнего мираматериальные, социологические, даже психологические особенности героев и обстановки, в которой они действуют,- т. е. осуществляющая феноменологическую редукцию (!), погружает нас в этот фантастический мир героев Достоевского. Встреча с Другим, с ближним в этом мире,- -это не просто эмпирическая встреча с попутчиком жизни, это всегда установление глубинного диалога, раскрывающего правду каждого перед лицом Бога. Еще раз вспомним Шатова из «Бесов», характеризующего подобный диалог: «Мы два существа и сошлись в беспредельности... в последний раз в мире» (Дзо. Т. 11: 195). Человек в этом диалоге как бы поднимается над самим собой, преодолевает все случайное и поверхностное своей жизни и предстает перед нами своим онтологическим лицом (ликом), отражающим, согласно христианским представлениям, образ Божий. Этот онтологический лик человека уже предчувствуется нами в общении с ним, он как бы просвечивает через всю эмпирию жизненных событий, причем интересно, что он не только постепенно выявляет себя, но и, как в зеркале, показывает нам и наш собственный лик и намекает на глубинный смысл нашей встречи... Вот, герой «Кроткой» с револьвером в кармане подслушивает происходящий в соседней комнате разговор его жены с Ефимовичем. Казалось бы, он готов на все!..

И что ж: вышло то (я к чести моей говорю это), вышло точь-в точь то, что я предчувствовал и предполагал, хоть и не сознавая, что я предчувствую и предполагаю это. Не знаю, понятно ли выражаюсь (Дзо. Т. 24: 19).

Жена героя демонстрирует свою верность и свое целомудрие в этой встрече, причем так, что вызывает восхищение супруга. Но разве не знал он этого заранее?.. Разве не предчувствовал? Да, да, конечно, но «нажитые в разврате болезни» не позволяли увидеть в этом предчувствии правду. Прилоги страха, гордыни, тщеславия искажали образ ближнего, и нужно было это испытание подслушиванием, а потом и трагедия самоубийства, чтобы истина выступила во всей своей убедительности, истина о супруге и о самом себе: «Измучил я ее-вот что!» (там же: 35 )

Можно было бы привести множество мест из произведений Достоевского, свидетельствующих о его сознательном использовании того метода, который в дальнейшем получил название философской феноменологии. Любопытно, что, не будучи профессиональным философом, не строя специально философской системы, Достоевский довольно умело 
пользуется техникой феноменологического метода, например, редукцией разных порядков. Все это важно не для того, чтобы еще раз доказать, что «слоны произошли из России». Эти наблюдения, на мой взгляд, показывают источник происхождения феноменологического метода, анализа сознания. В христианской культуре существовала,- и существует! - многовековая традиция покаянного анализа совести. Именно ее воспринял великий русский писатель в своем творчестве, и именно она, в конце концов, служила источником феноменологического анализа сознания.

\section{СОКРАЩЕНИЯ}

Дзо Достоевский Ф. М. Полное собрание сочинений : в 3 т. / под ред. В.Г. Базанова, Г. М. Фридлендера, В. В. Виноградова. - М., Л. : Наука, 1972-1990.

Т. 6 : Преступление и наказание : роман в 6 ч. с эпилогом / под ред. Л. Д. Опульской. - 1973.

Т. 9 : Идиот. Вечный муж. Наброски, 1867-1870. Рукописные ред. под ред. В. Г. Базанова, И. А. Битюговой. - 1974.

Т. 10 : Бесы : роман / под ред. В. Г. Базанова, Т. П. Головановой. 1974.

Т. 11 : Повести и рассказы, 1862-1866. Игрок : роман / под ред. Е. И. Кийко. - 1973 .

Т. 16 : Подросток / под ред. В. Г. Базанова, А. В. Архиповой. - 1976. T. 27 : Дневник писателя, 1881. Автобиографическое. Dubia / под ред. А. М. Березкина. -1984 .

\section{ЛИтЕРАТУРA}

Бахтин М. М. Проблемы поэтики Достоевского // Собрание сочинений. В 7 т. Т. 6 / под ред. С. Г. Бочарова, Л. С. Мелиховой. - М. : Русские словари, 2002. - С. 5-300.

Виноградов В. В. Стиль Пушкина. vII. Стиль повествовательной прозы Пушкина / Александр Пушкин. - 2021. - URL: http://pushkin-lit.ru/pushkin/ar ticles/vinogradov-stil-pushkina/stil-prozy-2.htm (дата обр. 15 февр. 2021).

Карякин Ю. Зачем Хроникер в «Бесах»? // Литературное обозрение. - 1981. № 4 . - C. $72-84$.

Лосский В. Н. Очерк мистического богословия Восточной церкви // Мистическое богословие. - Киев : Путь к Истине, 1991. - С. 95-260.

Наседкин Н. Н. Достоевский. Энциклопедия. - М. : Алгоритм, 2008.

Хайдеггер М. Бытие и время / пер. с нем. В.В. Бибихина. - М. : Ad Marginem, 1997 . 
Шелер М. Избранные произведения / пер. с нем. А. В. Денежкина, А. Н. Малинкина, А.Ф. Филлипова. - М. : Гнозис, 1994.

Katasonov, V. N. 2021. "Dostoyevskiy i fenomenologiya [Dostoevsky and Phenomenology]" [in Russian]. Filosofiya. Zhurnal Vysshey shkoly ekonomiki [Philosophy. Journal of the Higher School of Economics] 5 (3), 73-91.

\author{
VLADIMIR KATASONOV \\ Doctor of Letters in Philosophy and Theology, Professor \\ Saint Cyril and Methodius Institute for Advanced Studies (Moscow, Russia); \\ ORCID: 0000-0002-4933-3004
}

\title{
Dostoevsky and Phenomenology
}

Submitted: June 12, 2021. Reviewed: Aug. 26, 2021. Accepted: Aug. 28, 2021.

Abstract: The article examines the similarity of Fyodor Dostoevsky's artistic techniques and the methods of philosophical phenomenology. Due to the special tuning of the author's voice in the works of the writer, the universe of his characters is a kind of analogue of Husserl's Lebenswelt. The voice of the author, the narrator in the polyphonic novel serves as an intermediary, a kind of detector, with the help of which the human universe is studied, through which the fundamental spiritual position of the characters is revealed. It was not immediately that the Russian writer managed to find the compositional position of the narrator, whose vision on the one hand had to be comprehensive, and on the other - not to violate the open and dialogical atmosphere of the novels. Using the example of the analysis of the story "The Meek One", the similarity of Dostoevsky's techniques and the method of phenomenological reduction is shown. In the process of self-knowledge, the hero "brackets" all the surface layers of his life, social, psychological, and discovers the last truth about himself in the face of God. The author of the article understands this closeness not by chance: the very origin of the analysis of consciousness in phenomenology is connected with the tradition of the culture of repentance in the Christian Church.

Keywords: Polyphonic Novel, Author's Voice, Chronicler, Husserl's "Lebenswelt", Phenomenological Reduction, Penitential Analysis of Conscience.

DOI: $10.17323 / 2587-8719-2021-3-73-91$.

\section{REFERENCES}

Bakhtin, M. M. 2002. "Problemy poetiki Dostoyevskogo [Problems of Dostoevsky's Poetics]" [in Russian]. In vol. 6 of Sobraniye sochineniy [Collected Works], ed. by S. G. Bocharov and L.S. Melikhova, 5-300. 7 vols. Moskva [Moscow]: Russkiye slovari.

Dostoyevskiy, F. M. 1972-1990. Polnoye sobraniye sochineniy [Complete Works] [in Russian]. Ed. by V. G. Bazanov, G. M. Fridlender, and V. V. Vinogradov. 30 vols. Moskva [Moscow] and Leningrad: Nauka.

Heidegger, M. 1997. Bytiye i vremya [Sein und Zeit] [in Russian]. Trans. from the German by V. V. Bibikhin. Moskva [Moscow]: Ad Marginem.

Karyakin, Yu. 1981. "Zachem Khroniker v 'Besakh' ? [Why is there a Chronicler in 'Demons' ?]" [in Russian]. Literaturnoye obozreniye [Literary Review], no. 4: 72-84. 
Losskiy, V. N. 1991. "Ocherk misticheskogo bogosloviya Vostochnoy tserkvi [An Essay on the Mystical Theology of the Eastern Church]" [in Russian]. In Misticheskoye bogosloviye [Mystical Theology], 95-26o. Kiyev [Kiev]: Put' k Istine.

Nasedkin, N. N. 2008. Dostoyevskiy. Entsiklopediya [Dostoevsky. Encyclopedia] [in Russian]. Moskva [Moscow]: Algoritm.

Scheler, M. 1994. Izbrannyye proizvedeniya [Selected Works] [in Russian]. Trans. from the German by A. V. Denezhkin, A. N. Malinkin, and A. F. Fillipov. Moskva [Moscow]: Gnozis. Vinogradov, V. V. 2021. "Stil' Pushkina. VII. Stil' povestvovatel'noy prozy Pushkina [The Style of Pushkin. VII. The Style of Pushkin's Narrative Prose]" [in Russian]. Aleksandr Pushkin. Accessed Feb. 15, 2021. http://pushkin-lit.ru/pushkin/articles/vinogradov-stil-pushk ina/stil-prozy-2.htm. 